\title{
Groundwater quality on dairy farms in central South Africa
}

\author{
Leana Esterhuizen ${ }^{1 *}$, Annabel Fossey ${ }^{1}$ and Elsa Potgieter ${ }^{2}$ \\ 'Department of Life Sciences, Faculty of Health and Environmental Sciences, Central University of Technology, Private Bag 20539, Bloemfontein, 9301, \\ South Africa \\ ${ }^{2}$ Microbiology Laboratory Services, Mangaung Metropolitan Municipality, PO Box 3704, Bloemfontein, 9300, South Africa
}

\section{ABSTRACT}

Dairy farms in central South Africa depend mostly on groundwater for domestic needs and dairy activities. Groundwater samples were collected from 37 dairy farms during 2009 and 2013. Sixteen water quality parameters were tested and compared to the standard. Four parameters in 2009 and six in 2013 exhibited $100 \%$ compliance with the standard. Nitrate, Escherichia coli and total coliforms showed relatively low compliance across farms and years. Almost all farms were noncompliant for hardness in both sampling years. $T$-tests revealed significant changes from 2009 to 2013 for $\mathrm{pH}(t=2.580$; $p=0.006)$, hardness $(t=2.197 ; p=0.016)$ and potassium $(\mathrm{K})(t=1.699 ; p=0.0468)$. For hardness, approximately $45 \%$ of the farms in 2009, and $57 \%$ in 2013, posed a health risk to sensitive consumers. More than $50 \%$ of the farms in both years demonstrated levels of nitrates that could pose a health risk, particularly for babies. High levels of coliforms and E. coli were found, indicating a health risk for clinical infections in consumers. The number of farms presenting 3 or more parameters with a health risk more than doubled from $13.5 \%$ in 2009 to $27.0 \%$ in 2013 .

Keywords: Water quality, groundwater, E. coli, coliforms, nitrate, hardness, dairy farms

\section{INTRODUCTION}

Dairy farming is the fourth largest agricultural industry in South Africa, representing $6 \%$ of the gross value of overall agricultural production (Mkhabela et al., 2010). The dairy industry is also a major contributor to the South African economy through employment, with about 60000 farm workers employed by more than 4000 milk producers (DAFF, 2012). The total number of milk producers, as recorded in January 2008, was 3665 , of which 919 were situated in the Free State Province (Mkhabela et al., 2010). The number of milk producers in the Free Sate decreased from 919 in 2008 to 498 in 2013 (Milk SA, 2013).

Dairy enterprises utilise water for all steps of the dairy industry, including cleaning, sanitisation, heating, cooling and floor washing. Dairy farm effluent, which refers to manure and urine deposited throughout the milking process, is diluted while washing the milking shed floor (Williamson et al., 1998; Hooda et al., 2000). Animal waste in dairy effluent is a major source of pollution through nutrient enrichment of streams and groundwater which may, in turn, have a significant impact on the environment (Wilcock et al., 1999; Ali et al., 2006; Atalay et al., 2008; Kay et al., 2008; Van der Schans et al., 2009).

The harmful effects of agricultural activities on groundwater (Gillingham and Thorrold, 2000; Dahiya et al., 2007; Monaghan et al., 2009) are becoming more and more of a concern worldwide (Mohammad and Kaluarachchi, 2004). In South Africa, most dairy effluent is discharged onto pastures and land (Strydom et al., 1993) and has been shown to pollute groundwater (Tredoux et al., 2000). Therefore, disposal practices for dairy effluent and manure in dairy enterprises are

This paper was originally presented at the 2014 Water Institute of Southern Africa (WISA) Biennial Conference, Mbombela, 25-29 May 2014

* To whom all correspondence should be addressed.

푤 +27 51507 3850; e-mail: lesterhu@cut.ac.za currently undergoing critical revision to reduce their impact on groundwater quality (Goss and Richards, 2008).

Most dairy farms in the Free State utilise groundwater as a human drinking water source and for all dairy activities. Farm groundwater is rarely treated in South Africa. Therefore, if farm effluent and manure is disposed of in an inappropriate manner, faecally derived pathogens and nitrates may be introduced into groundwater which, in turn, may pose a risk to human health when the water is used as drinking water and in dairy activities (Harter et al., 2002; Oliver et al., 2009). Faecal contamination of groundwater has been linked to outbreaks of various water-borne infections (Krolik et al., 2013). Nitrates have been implicated in methaemoglobinaemia and also a number of inconclusive health outcomes (Fewtrell, 2004). Acquired methaemoglobinaemia is primarily an issue for infants less than 6 months old (Manassaram et al., 2010).

In South Africa, the quality of water used on dairy farms must meet minimum standards in order to comply with the conditions set out in Regulation 961 (RSA, 2012). Water used in a commercial dairy must comply with the South African National Standard 241 (SANS, 2011) for drinking water. Because the groundwater on dairy farms in South Africa is rarely monitored, this study was undertaken to assess compliance of groundwater to the SANS 241 (SANS, 2011) drinking water standard on dairy farms in the central Free State.

\section{METHODS}

Groundwater samples were collected from the point of use on 37 dairy farms located in the districts of Motheo, Xhariep and Lejweleputswa in the central Free State, South Africa. Water samples were collected during 2009, and repeated in 2013. Sixteen groundwater quality parameters were analysed, namely: electrical conductivity (EC), $\mathrm{pH}$, total hardness, chloride $(\mathrm{Cl})$, sulphate $\left(\mathrm{SO}_{4}\right)$, phosphate $\left(\mathrm{PO}_{4}\right)$, nitrate $\left(\mathrm{NO}_{3}\right)$, fluoride $(\mathrm{F})$, calcium $(\mathrm{Ca})$, magnesium $(\mathrm{Mg})$, sodium $(\mathrm{Na})$, 

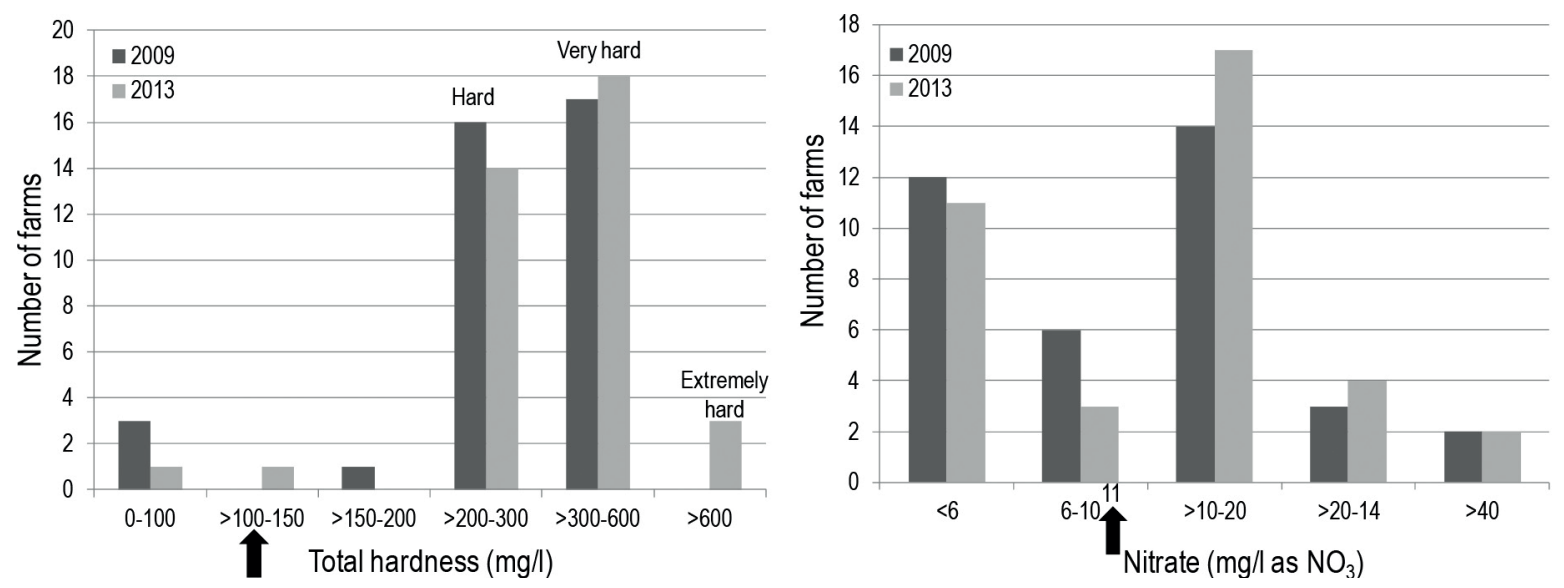

Figure 1

Distribution of measurements for (a) total hardness, and (b) nitrate (arrow indicates the limit of the South African National Standard)

potassium (K), heterotrophic plate count (HPC), total coliforms and Escherichia coli. Total dissolved solids (TDS) were estimated by multiplying EC by the factor of 6.5 (WRC, 1998). Standard sampling and analytical procedures were followed for the physical and chemical parameters, as prescribed by SANS 241 (SANS, 2011) and the Department of Water Affairs (DWAF, 2006).

For the microbiological analyses, the instructions of the manufacturers of Petrifilm ${ }^{\circ}$ and Colilert'-18 were followed. Prior to sampling, a tap was first flamed and thereafter left to run freely for at least 2 minutes. Electrical conductivity and $\mathrm{pH}$ were measured in situ using a MARTINI MI $806 \mathrm{pH} / \mathrm{EC} /$ temperature portable meter. For the chemical parameters, water was collected in $500 \mathrm{~m} \ell$ bottles while, for the microbial analysis, sterile $100 \mathrm{~m} \ell$ bottles were used. All samples were placed in an ice box and transported to the laboratory where they were stored in a refrigerator at a temperature of $4^{\circ} \mathrm{C}$ until analysis was completed. Chemical analyses were conducted by the Institute of Groundwater Studies in Bloemfontein. Water samples for microbiological analysis were processed in the microbiology laboratory of Mangaung Metropolitan Municipality in Bloemfontein. $T$-tests were performed on the different water quality parameters to ascertain if significant differences existed between the 2 sampling years.

\section{RESULTS}

Of the 16 water quality parameters that were measured, 4 parameters in 2009 and 6 in 2013 exhibited 100\% compliance with the standard (Table 1 ). Three parameters, namely nitrate, E. coli and total coliforms, showed relatively low compliance across the farms and years. Approximately onethird of the farms were non-compliant for E. coli and more than $50 \%$ for total coliforms in both sampling years. For hardness, almost all the farms were non-compliant in both sampling years. $T$-tests were performed to ascertain if there were any changes in the quality of the drinking water from 2009 to 2013. Only three of the parameters demonstrated significant change from 2009 to 2013 , namely $\mathrm{pH}(t=2.580$; $p=0.006)$, hardness $(t=2.197 ; p=0.016)$ and $\mathrm{K}(t=1.699$; $p=0.0468)$.

\section{Health and economic implications}

Hard water generally poses no health risk for consumers; however, water that is very hard or extremely hard could result in chronic health effects in sensitive groups, such as the aged and immune-compromised (WRC, 1998). In this study, approximately $45 \%$ of the farms in 2009 and $57 \%$ in 2013 demonstrated water that poses a risk for these sensitive consumer groups (Fig. 1a).

Hard water used for domestic purposes results in scale deposition, particularly in heating appliances, and also requires an increased use of soap (Rubenowitz-Lundin and Hiscock, 2013). The groundwater on many farms tested as hard or very hard, while the water on a few farms tested as extremely hard (Fig. 1a). Because water is used in all dairy cleaning operations, these levels of hard water could add an additional cost to the running of a dairy by reducing the life span of equipment and increasing the amount of soap used.

High levels of nitrate in drinking water are of concern for babies, particularly as groundwater is the only source of drinking water on all the farms studied (WRC, 1998). More than $50 \%$ of the farms studied, in both years, demonstrated levels of nitrates that could pose a health risk (Fig. 1b). Of particular concern were the few farms with levels of nitrates exceeding 40 $\mathrm{mg} / \ell$ which pose an acute risk for babies. Furthermore, nitrate poisoning of livestock could result in animal losses (Tredoux et al., 2000). Other adverse health effects in animals include increased incidence of stillborn calves and abortion, lower milk production and reduced weight gain (Tredoux et al., 2004).

The high levels of coliforms found in the groundwater on many of the farms are of concern, particularly for sensitive groups. Counts of $10-100 / \mathrm{m} \ell$ could result in clinical infections, and counts of 100-1000/m could cause infections even with once-off consumption (WRC, 1998). Counts of $>1000 / \mathrm{m} \ell$ in the groundwater on $18.9 \%$ of the farms in 2009 , and $5.6 \%$ in 2013 , pose serious health risks for all users (WRC, 1998) (Fig. 2a).

Escherichia coli, on the other hand, poses a health risk to consumers at much lower levels, particularly to sensitive groups (WRC, 1998). Clinical infections are common, even with onceoff consumption, at counts of $>10-100 / \mathrm{m} \ell$ and serious health effects are common in all users at counts of $>100 / \mathrm{m} \ell$ (Fig. 2b). These risks are equally prevalent when untreated, polluted groundwater is used for food preparation (WRC, 1998). 
TABLE 1

Summary statistics of the water quality parameters measured in 2009 and 2013

\begin{tabular}{|c|c|c|c|c|c|c|c|c|c|c|}
\hline \multirow{2}{*}{$\begin{array}{l}\text { Parameters } \\
\text { (Standard limit) }\end{array}$} & \multicolumn{2}{|c|}{ Minimum } & \multicolumn{2}{|c|}{ Maximum } & \multicolumn{2}{|c|}{ Median } & \multicolumn{2}{|c|}{ Mean (SD) } & \multicolumn{2}{|c|}{$\begin{array}{c}\% \\
\text { Compliance }\end{array}$} \\
\hline & 2009 & 2013 & 2009 & 2013 & 2009 & 2013 & 2009 & 2013 & 2009 & 2013 \\
\hline $\mathrm{EC}(170 \mathrm{mS} / \mathrm{m})$ & 54.00 & 44.50 & 231.00 & 282.00 & 79.40 & 83.30 & $97.83(47.23)$ & $95.45(46.69)$ & 89.19 & 97.30 \\
\hline TDS (1 $200 \mathrm{mg} / \ell)$ & 351.00 & 289.25 & 1501.50 & 1833.00 & 516.10 & 541.45 & $635.89(307.01)$ & $620.40(303.45)$ & 89.19 & 89.19 \\
\hline $\mathrm{pH}(5-9.7)$ & 7.12 & 7.04 & 8.34 & 8.09 & 7.70 & 7.51 & $7.66(0.32)$ & $7.49(0.25)$ & 100.00 & 100.00 \\
\hline $\begin{array}{l}\text { Total hardness } \\
(100 \mathrm{mg} / \ell)\end{array}$ & 3.59 & 42.90 & 471.00 & 1544.77 & 294.00 & 315.28 & $280.52(102.73)$ & $379.68(254.73)$ & 8.11 & 2.70 \\
\hline $\begin{array}{l}\text { Chloride }(\mathrm{Cl}) \\
(300 \mathrm{mg} / \ell)\end{array}$ & 12.00 & 19.83 & 462.00 & 474.10 & 47.00 & 55.20 & $89.81(112.33)$ & $87.19(94.88)$ & 91.89 & 97.26 \\
\hline $\begin{array}{l}\text { Sulphate }\left(\mathrm{SO}_{4}\right) \\
(500 \mathrm{mg} / \mathrm{\ell})\end{array}$ & 15.00 & 14.60 & 194.00 & 266.19 & 42.00 & 42.81 & $55.19(45.95)$ & $58.92(50.57)$ & 94.59 & 100.00 \\
\hline $\begin{array}{l}\text { Phosphate }\left(\mathrm{PO}_{4}\right) \\
(0.1 \mathrm{mg} / \ell)\end{array}$ & 0.10 & $<1.00$ & 5.46 & $<0.10$ & 0.25 & $<0.10$ & $1.75(2.47)$ & $<0.32(0.39)$ & 94.59 & 100.00 \\
\hline $\begin{array}{l}\text { Nitrate }\left(\mathrm{NO}_{3}\right) \\
(11 \mathrm{mg} / \ell)\end{array}$ & 0.39 & 0.65 & 68.00 & 79.18 & 10.61 & 12.50 & $13.70(15.03)$ & $14.66(14.99)$ & 56.76 & 40.54 \\
\hline $\begin{array}{l}\text { Fluoride (F) } \\
(1.5 \mathrm{mg} / \ell)\end{array}$ & 0.13 & 0.08 & 1.43 & 0.96 & 0.37 & 0.35 & $0.42(0.25)$ & $0.38(0.19)$ & 100.00 & 100.00 \\
\hline $\begin{array}{l}\text { Calcium (Ca) } \\
(150 \mathrm{mg} / \ell)\end{array}$ & 38.40 & 10.70 & 406.00 & 295.71 & 73.90 & 67.47 & $104.96(90.72)$ & $80.53(48.94)$ & 86.49 & 94.59 \\
\hline $\begin{array}{l}\text { Magnesium }(\mathrm{Mg}) \\
(70 \mathrm{mg} / \ell)\end{array}$ & 11.10 & 3.94 & 152.00 & 196.46 & 33.80 & 35.35 & $45.66(34.61)$ & $43.50(33.08)$ & 89.19 & 97.30 \\
\hline $\begin{array}{l}\text { Sodium }(\mathrm{Na}) \\
(200 \mathrm{mg} / \ell)\end{array}$ & 15.70 & 21.23 & 142.00 & 162.91 & 55.40 & 59.92 & $60.28(31.51)$ & $66.22(32.77)$ & 100.00 & 100.00 \\
\hline $\begin{array}{l}\text { Potassium }(\mathrm{K}) \\
(50 \mathrm{mg} / \mathrm{\ell})\end{array}$ & 0.33 & 0.19 & 158.00 & 10.65 & 4.17 & 4.01 & $13.91(33.35)$ & $4.55(3.03)$ & 100.00 & 100.00 \\
\hline $\begin{array}{l}\text { HPC } \\
(1000 \text { counts } / 100 \mathrm{~m} \ell)\end{array}$ & 0.00 & 5.00 & 27000.00 & 32000.00 & 1080.00 & 91.50 & $\begin{array}{c}1286.30(4 \\
630.20)\end{array}$ & $\begin{array}{l}1515.80 \\
(5798.55)\end{array}$ & 81.1 & 91.9 \\
\hline $\begin{array}{l}\text { Total coliforms } \\
(<10 \text { counts } / 100 \mathrm{~m} \ell)\end{array}$ & 0.00 & 0.00 & 2419.00 & 2419.20 & 42.00 & 11.60 & $506.50(875.50)$ & $258.30(581.66)$ & 40.5 & 45.9 \\
\hline $\begin{array}{l}\text { E. coli (not detected } \\
\text { in } 100 \mathrm{~m} \ell)\end{array}$ & 0.00 & 0.00 & 2419.00 & 45.00 & 0.00 & 0.00 & $84.50(399.13)$ & $3.90(59.46)$ & 70.3 & 59.5 \\
\hline
\end{tabular}

$\mathrm{EC}=$ electrical conductivity; $\mathrm{HPC}=$ heterotrophic plate count; TDS = total dissolved solids; $\mathrm{SD}=$ standard deviation
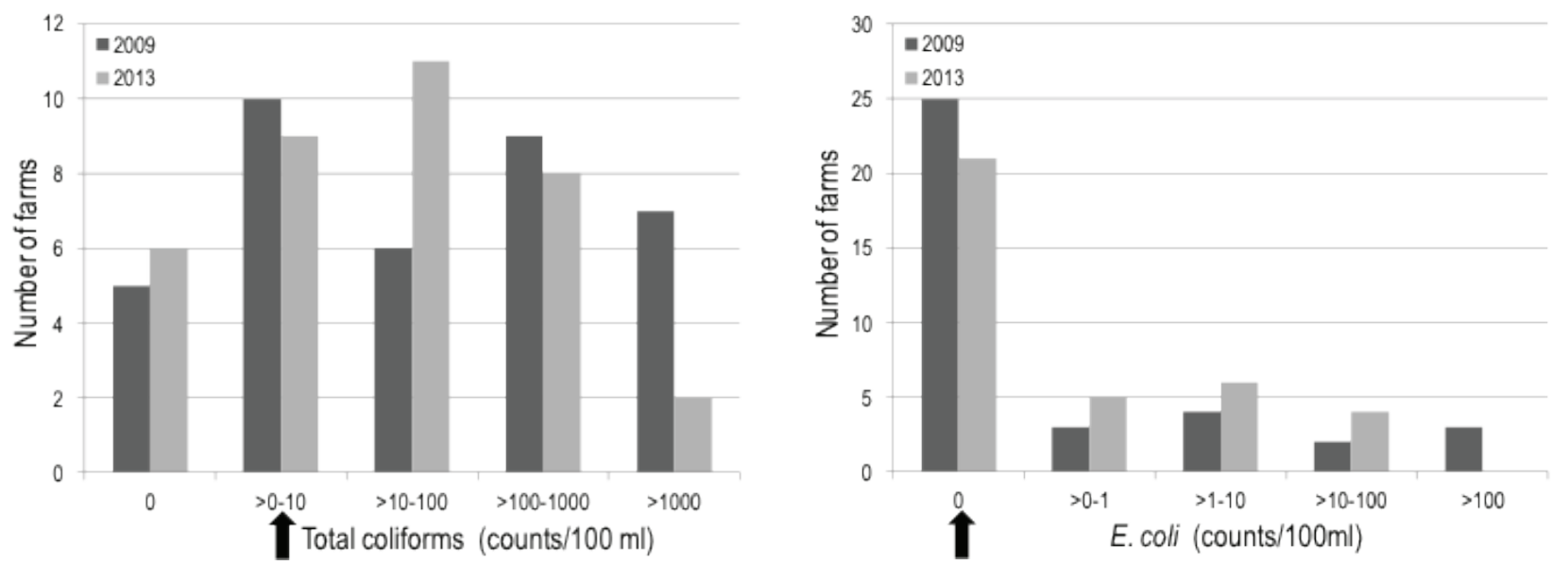

Figure 2

Distribution of measurements for (a) total coliforms, and (b) E. coli (arrow indicates the limit of the South African standard) 
The 4 parameters (hardness, nitrate, coliforms and E. coli) were used to ascertain the health risk exposure of consumers of groundwater on the farms. It was found that the number of farms presenting with 3 or 4 of the parameters at a level of risk, more than doubled from $13.5 \%$ in 2009 to $27.0 \% 2013$.

\section{DISCUSSION AND CONCLUSIONS}

The region in which this study was undertaken is known for its hard water, caused mainly by the natural geology of the region. Nitrate enrichment of water can be attributed mostly to animal waste and run-off from the dairies (Wilcock et al., 1999). On some of the farms the nitrate levels were exceptionally high, up to 7 times greater than the South African specified health limit of $11 \mathrm{mg} / \ell$ (SABS, 2011), which is more stringent than the $50 \mathrm{mg} / \ell$ specified for nitrates by the World Health Organisation (WHO, 2011). On 2 farms in 2009 and on 1 farm in 2013, the nitrate measurement exceeded toxic levels of $>50 \mathrm{mg} / \ell$ (Spalding and Exner, 1993). A groundwater study conducted in the rural areas of South Africa indicated that increasing nitrate levels in groundwater are hazardous to bottle-fed infants as well as to livestock (Tredoux et al., 2000).

A further concern is the high levels of coliforms and $E$. coli that were detected in the water used for domestic purposes and dairy activities. The number of total coliform and E. coli found in the drinking water suggests that poor sanitation conditions and practices are potential reasons for the high presence of microbiological contaminants (Gwimbi, 2011). Although most coliforms do not cause disease, they are indicators of the presence of other disease-causing organisms (Wu et al., 2011). At the high levels found in this study, coliforms could pose a health threat even with onceoff consumption (WRC, 1998). At more than 55\% of the farms, E. coli contamination of drinking water fell into the categories of intermediate to very high risk, according to the WHO (1997). The E. coli presence indicates faecal contamination and, therefore, poses a health threat to humans and animals residing on the farms (Pell, 1997). Immunecompromised patients, suffering from HIV/AIDS, are particularly vulnerable.

Factors contributing to the contamination of milk include contact with animals and personnel engaged in milk processing, unhygienic milking equipment, poor quality water used in the dairy, and poor herd health (Altalhi and Hassan, 2009). Although the process of pasteurisation is responsible for improving safety and lengthening the shelf life of dairy products, it does not eliminate all microorganisms and their enzymes, spores and toxins. The thermal destruction process is logarithmic and eliminates bacteria at a rate that is proportional to the number of bacteria present in raw milk (Le Jeune and Rajala-Schultz, 2009). In instances where the bacterial count is high in raw milk, pasteurisation will not be able to kill all bacteria within the short period of time of its application (Lund et al., 2002). Milk buyers in South Africa apply a sliding scale for good quality milk and a penalty system for milk with low bacteriological quality, when determining the value of the raw milk (Clover, 2013). Furthermore, the high bacterial content in the water could compromise the quality of dairy products and other farming produce (Jones, 1999). This study strongly suggests a revision of waste water management strategies on dairy farms in the Free State.

\section{ACKNOWLEDGEMENTS}

The authors wish to thank the National Research Foundation for funding this project as well as the microbiology laboratory of Mangaung Metropolitan Municipality for their collaboration.

\section{REFERENCES}

ALI I, MORIN S, BARRINGTON S, WHALEN J, BONNELL R and MARTINEZ J (2006) Surface irrigation of dairy farm effluent, Part I: Nutrient and bacterial load. Biosyst. Eng. 95 (4) 547-556.

ALTALHI AD and HASSAN SA (2009) Bacterial quality of raw milk investigated by Escherichia coli and isolates analysis for specific virulence-gene markers. Food Control 20 913-917.

ATALAY A, PAO S, JAMES M, WHITEHEAD B and ALLEN A (2008) Drinking water assessment at underserved farms in Virginia's coastal plain. J. Environ. Monit. 4 53-64.

CLOVER (2013) Milk procurement protocol. URL: http://www.clover. co.za/milk-procurement-model (Accessed 1 November 2013).

DAHIYA S, SINGH B, GAUR S, GARG VK and KUSHWAHA HS (2007) Analysis of groundwater quality using fuzzy synthetic evaluation. J. Hazardous Mater. 147 938-946

DAFF (DEPARTMENT of AGRICULTURE, FORESTRY and FISHERIES) (2012) A profile of the South African dairy market value chain. URL: http://www.nda.agric.za/doaDev/sideMenu/ Marketing/Annual\%20Publications/Commodity\%20Profiles/ Livestock/Dairy\%20Market\%20Value\%20Chain\%20Profile\%20 2012-2013.pdf (Accessed 26 October 2013).

DWAF (DEPARTMENT OF WATER AFFAIRS AND FORESTRY) (2006) Minimum requirements for sampling drinking water systems. Department of Water Affairs and Forestry, Pretoria, South Africa.

FEWTRELL L (2004) Drinking-water nitrate, methemoglobinaemia, and global burden of disease: a discussion. Environ. Health Perspect. 112 (14) 1371-1374.

GILLINGHAM AG and THORROLD BS (2000) A review of New Zealand research measuring phosphorus in run-off from pasture. $J$. Environ. Qual. 29 88-96.

GOSS M and RICHARDS C (2008) Development of a risk-based index for source water protection planning, which supports the reduction of pathogens from agricultural activity entering water resources. J. Environ. Manage. 87 623-632.

GWIMBI P (2011) The microbial quality of drinking water in Manonyane community: Maseru District (Lesotho). Afr. Health Sci. 11 (3) 474-480.

HARTER T, DAVIS H, MATHEWS MC and MEYER RD (2002) Shallow groundwater quality on dairy farms with irrigated forage crops. J. Contam. Hydrol. 55 287-315.

HOODA PS, EDWARDS UAC, ANDERSON HA and MILLER A (2000) A review of water quality concerns in livestock farming areas. Sci. Total Environ. 250 143-167.

JONES DL(1999) Potential health risks associated with the persistence of Escherichia coli 0157 in agricultural environments. Soil Use Manage. 15 (2) 78-83.

KAY D, CROWTHE J, FEWTRELL L, FRANCIS AC, HOPKINS M, KAY C, MCDONALD AT, STAPLETON CM, WATKINS J, WILKINSON J and WYER MD (2008) Quantification and control of microbial pollution from agriculture: a new policy challenge? Environ. Sci. Polic. 2 171-184.

KROLIK J, MAIER A, EVANS G, BELANGER P, HALL G, JOYCE A and MAJURY A (2013) A spatial analysis of private well water Escherichia coli contamination in southern Ontario. Geospat. Health 8 (1) 65-75.

LE JEUNE JT and RAJALA-SCHULTZ PJ (2009) Food safety: unpasteurised milk: a continued public health threat. Clin. Infect. Dis. 48 (1) 93-100.

LUND BM, GOULD WG and RAMPLING AM (2002) Pasteurisation of milk and the heat resistance of Mycobacterium avium subsp. paratuberculosis: a critical review of the data. Int. J. Food Microbiol. 77 135-145. 
MANASSARAM DM, BACKER LC, MESSING R, FLEMING LE, LUKE B and MONTEILH CP (2010) Nitrates in drinking water and methemoglobin levels in pregnancy: a longitudinal study. Environ. Health 9 (60) 1-12.

MILK SA (MILK SOUTH AFRICA) (2013) Lacto data statistics. Milk South Africa 16 URL: http://www.mpo.co.za/lactodata.html (Accessed 18 December 2013).

MKHABELA T, PIESSE J, THIRTLE C and VINK N (2010) Modelling efficiency with farm-produced inputs: dairying in KwaZulu-Natal, South Africa. Agrekon. 49 (1) 102-121.

MOHAMMAD NA and KALUARACHCHI JJ (2004) Assessment and management of long-term nitrate pollution of ground water in agriculture-dominated watersheds. J. Hydrol. 295 225-245.

MONAGHAN RM, CAREY PL, WILCOCK RJ, DREWRY JJ, HOULBROOKE, DJ, QUINN JM and THORROLD BS (2009) Linkages between land management activities and stream water quality in a border dyke-irrigated pastoral catchment. Agric. Ecosyst. Environ. 129 201-211.

OLIVER DM, FISH RD, HODGSON CJ, HEATHWAITE AL CHADWICK DR, and WINTER M (2009) A cross-disciplinary toolkit to assess the risk of faecal indicator loss from grassland farm systems to surface waters. Agric. Ecosyst. Environ. 129 401-412

PELL AN (1997) Manure and microbes: Public and animal health problem? J. Dairy Sci. 80 267-2681.

RSA (REPUBLIC OF SOUTH AFRICA) (2012) Regulation relating to hygiene requirements for milking shed, the transport of milk and related matters. Government notice R. 961 of 23 November 2012 promulgated under Foodstuffs, Cosmetics and Disinfectants Act, 54 of 1972. Government Printer, Pretoria.

RUBENOWITZ-LUNDIN E and HISCOCK KM (2013) Water hardness and health effects. In Selinus O (ed.) Essentials of Medical Geology. Springer, Dordrecht. 337-350.

SABS (SOUTH AFRICAN BUREAU OF STANDARDS) (2011) SANS 241-1:2011. Drinking water. Part 1. Microbial, physical, aesthetic and chemical determinants. SABS, Pretoria.
SPALDING RF and EXNER ME (1993) Occurrence of nitrate in groundwater: A review. J. Environ Qual. 22 392-402.

STRYDOM JP, MOSTERT JF and BRITZ TJ (1993) Effluent production and disposal in the South African dairy industry: A postal survey. Water SA 19 (3) 253-258.

TREDOUX G, ENGELBRECHT JFP, TALMA AS and ISRAEL S (2004) Groundwater nitrate: a rural water supply threat. In: 5 th WaterNet/ WARFSA Annual Symposium, 2-4 November 2004, Windhoek.

TREDOUX G, TALMA AS and ENGELBRECHT JFP (2000) The increasing nitrate hazard in groundwater in the rural areas. In: WISA Biennial Conference, 28 May-1 June 2000, Sun City, South Africa.

VAN DER SCHANS ML, HARTER T, LEIJNSE A, MATHEWS MC and MEYER RD (2009) Characterising sources of nitrate leaching from an irrigated dairy farm in Merced County, California. $J$ Contam. Hydrol. 110 9-21

WHO (WORLD HEALTH ORGANISATION) (1997) Guidelines for Drinking Water Quality, $2^{\text {nd }}$ edition, Vol. III, Surveillance and Control of Community Supplies. World Health Organisation, Geneva.

WHO (WORLD HEALTH ORGANISATION) (2011) Guidelines for Drinking Water Quality (4 $4^{\text {th }}$ edn) World Health Organisation, Geneva.

WILCOCK RJ, NAGELS JW, RODDA HJE, O'CONNER MB, THORROLD BS and BARNETT JW (1999) Water quality of a lowland stream in a New Zealand dairy farming catchment. N. Z. J. Mar. Freshwater Res. 33 683-696.

WILLIAMSON JC, TAYLOR MD, TORRENS RS and VOJVODICVUKOVIC M (1998) Reducing nitrogen leaching from dairy farm effluent-irrigated pasture using dicyandiamide: alysimeter study. Agric. Ecosyst. Environ. 69 81-88.

WRC (WATER RESEARCH COMMISSION) (1998) Quality of Domestic Water Supplies, Volume 1: Assessment guide. WRC Report No. TT101/98. Water Research Commission, Pretoria.

WU J, LONG SC, DAS D and DORNER SM (2011) Are microbial indicators and pathogens correlated? A statistical analysis of 40 years of research. J. Water Health 9 (2) 265-278. 